\title{
THE ROLE OF SATISFACTION AND TRUST MEDIATE THE EFFECT OF SERVICE QUALITY ON CUSTOMER LOYALTY INDIHOME IN THE CITY OF DENPASAR
}

\author{
Ferdiansyah Aldino, Suprapti Ni Wayan Sri \\ Faculty of Economics and Business, University of Udayana, Bali, Indonesia \\ *E-mail: ferdiansyahaldino@gmail.com
}

\begin{abstract}
Since the determination of Covid-19 as a pandemic by the World Health Organization (WHO), various public reactions have emerged. There are people who feel afraid, angry, panicked, confused, and sad about this pandemic. The government issued a number of policies, ranging from large-scale social restrictions called PSBB, to work from home, better known as WFH. Many customers have complained through Twitter social media because of dissatisfaction with the Indihome network, which had problems when carrying out work from home activities in the midst of the Covid-19 pandemic. The purpose of this study is to discuss the role of satisfaction and trust in mediating the effect of service quality on customer loyalty. The population in this study was Indihome customers in Denpasar City. The sample of this research are 160 respondents, the sampling method is non-probability in the form of purposive sampling. Testing the research hypotheses completed by using Structural Equation Modeling (SEM) analysis techniques based on Partial Least Square (PLS). The results showed that service quality had a positive and significant effect on customer satisfaction, trust and loyalty; and satisfaction and trust are able to mediate the effect of service quality on customer loyalty significantly. Satisfaction and trust in this study partially mediate. Theoretical implications can contribute to the existing literature, especially regarding service quality, satisfaction, trust and customer loyalty of Indihome. The practical implications of this research are expected to be able to contribute and understand the management of Indihome, especially in Denpasar City, regarding how satisfaction and trust mediate service quality on customer loyalty.
\end{abstract}

\section{KEY WORDS}

Service quality, satisfaction, trust, customer loyalty.

Since the determination of Covid-19 as a pandemic by the World Health Organization (WHO), various public reactions have emerged. There are people who feel afraid, angry, panicked, confused, and sad about this pandemic. The impact of Covid-19 is huge and global. Not only affects the level of public health in particular, but also affects economic, social, psychological, cultural, political, government, education, sports, religious activities, and others. Therefore, appropriate government policies are needed to prevent and overcome this Covid-19. The government not only issues policies to prevent and cure patients infected with Covid-19, but also policies to overcome the social, psychological, and economic impacts caused by Covid-19. To prevent the spread and contagion of Covid-19 from spreading widely into the community, the government has made a series of policies to deal with it. The government issued a number of policies, ranging from large-scale social restrictions called PSBB, to work from home, better known as WFH.

The policy issued by the government has forced many individuals or groups from the habit of communicating or carrying out normal or face-to-face activities (offline) to become completely online. This pandemic condition has changed the lifestyle of the majority of the people to be completely online, such as working, studying, worshiping and shopping from home online. This is to support the government to prevent the spread of Covid-19. The effect of the implementation of WFH and PSBB raises the need for internet access at home and cellular data via telephone, laptop, computer and tablet. This is an opportunity for one of the telecommunications providers to offer internet services, namely PT. Telkom Indonesia with its product Indonesia Digital Home (Indihome). With wide coverage, Indihome is available in 
490 regencies/cities in the country or about 95 percent of the 519 regencies/cities in Indonesia (Telkom.com). This breakthrough is a manifestation of Telkom's commitment to providing telecommunications and data infrastructure throughout Indonesia. Quoting from Kompas.com, the number of customers who currently use Indihome services is 8 million people or 85 percent of the entire market share in Indonesia. During the pandemic, Indihome experienced an increase in demand for new pairs of up to 47 percent compared to the previous year (Bisnis.com).

There is a high dependence on internet access (data and wifi packages) during the pandemic to support activities such as working, studying online, shopping, playing games and streaming videos, fast and stable internet is needed. Many customers have complained through Twitter social media because of dissatisfaction with the Indihome network, which had problems when carrying out work from home activities in the midst of the Covid-19 pandemic. Indihome became a trending topic on Twitter caused by several Indihome users who expressed their complaints due to poor network quality so they could not access the internet and there were several complaints with Indihome services who were not satisfied with customer service due to the slow response and lack of solutions (CNN Indonesia). Quoting Speedtest.net in 2020, Biznet was ranked first as the fastest broadband or home internet service provider in Indonesia with a score of 33.99, then followed by MyRepublic 33.20, Firstmedia 14.82 and Indihome 14.74. Then for the most stable home internet service in Indonesia with a score obtained 60.4 percent is MyRepublic, with a minimum download speed of 25Mbps and a minimum upload of 3Mbps, then followed by Biznet 59.0 percent, Firstmedia 26.0 percent and Indihome 19.7 percent (Speedtest.net). From the results of tests conducted by Speedtest.net that Indihome loses in terms of network speed and stability, so it is natural for many customers to complain about the network being less than optimal.

Online learning has several weaknesses, namely the use of the internet network requires adequate infrastructure, requires a lot of money, communication via the internet has various obstacles/slow (Pratiwi, 2020), (Joni et al, 2020), (Engko et al, 2020). Fast and stable internet service is the main thing to support all activities during WFH and PSBB. As the market leader in broadband service providers, Indihome must be fast in overcoming the lag behind its competitors. This will cause customers to switch to other broadband service providers, which can offer a better experience than Indihome. With the delivery of good service quality becomes one of the most important strategies to reduce retention and increase customer loyalty. One that affects the level of customer loyalty is service quality (Widjoyo et al, 2014).

This is supported by preliminary interviews conducted with 20 internet provider customers, 80 percent of them still subscribe to Indihome and 20 percent have switched to other providers. Indihome customers who expressed dissatisfaction were as much as 70 percent and 30 percent said they were satisfied. Based on these results, many customers are dissatisfied with the quality of the internet and the products promised by Indihome. This can be a potential customer to be disloyal and will tend to switch to another provider.

Every company will work hard in retaining its customers. Building satisfaction and trust is a factor in the formation of customer loyalty. Satisfaction is a feeling that arises based on the experience of consuming a product or service. Trust is all knowledge and conclusions made by customers about objects, attributes and benefits. Customer loyalty is formed because of satisfaction and trust, so that it will create a long-term relationship for the company. Customer loyalty will be built when there is customer trust in the company and satisfactory service quality from the company to customers (Darwin and Kunto, 2014). Service quality is the result of an evaluation process in which perceived and expected services are compared. When the quality of service is as expected or in accordance with customer expectations, a feeling of satisfaction and trust will arise in the product or service. It is important for Indihome to take care of its customers, because it is a guarantee of competitive advantage and has a long-term relationship for the company. The shift of customers to other competitors is one proof of the company's failure to maintain and provide customer desires. 
Currently, companies are not only faced with attracting new customers, but also have an obligation to retain customers. Loyalty has several antecedents, such as customer satisfaction, customer engagement, service quality and customer perceived value (Akamavi et al, 2015), (Raies et al, 2015), (Han and Hyun, 2018), (Bruneau et al, 2018). According to Kotler \& Keller (2016:153) loyalty has been defined as a deeply held commitment to repurchase a preferred product or service in the future despite situational influences and marketing efforts that have the potential to cause changes in customer behavior.

The appropriate quality of service is expected by customers to provide benefits in increasing revenue, through not switching customers, so that good service quality is an asset for the company to further develop and increase loyalty. In previous studies discussing the relationship between service quality variables and customer loyalty, including Hanifa, et al. (2018), Liang (2019), Asnawi, et al. (2019), Basri (2019), and Abror, et al. (2019). However, from a number of studies conducted there are differences in results. Research conducted by Liang (2019), Asnawi, et al. (2019), Basri (2019), shows that service quality has a positive and significant effect on customer loyalty. Different results are shown in Hanifa, et al. (2018) service quality has no significant effect on customer loyalty, the level of customer satisfaction with Gojek services still does not meet expectations and the barriers to switching are still very low which makes customers disloyal. Abror, et al. (2019), service quality does not have a significant effect on customer loyalty, Islamic bank customers in West Sumatra still do not feel good service quality, so that the decreased level of satisfaction causes a decrease in customer loyalty of Islamic banks in West Sumatra.

Customers who consume products or services on an ongoing basis are based on a level of satisfaction that matches or exceeds expectations. Satisfaction is able to influence customer loyalty based on service quality. This is supported by research conducted by Firmansyah, et al. (2018), Asnawi, et al. (2019), Slack (2019), Hartono and Salim (2020), Satisfaction is able to mediate positively and significantly the effect of service quality on customer loyalty. Trust arises because of the quality of service, this has an impact on customer loyalty. This is supported by research conducted by Pramana and Rastini (2016), Pramana and Jatra (2017), Hartono and Salim (2020), trust is able to mediate positively and significantly the effect of service quality on customer loyalty.

This study aims to explain the effect of service quality on customer loyalty mediated by satisfaction and trust. The existence of the role of satisfaction and trust as a mediation between service quality and customer loyalty can conceptually be described in a model or conceptual framework as shown in Figure 1.

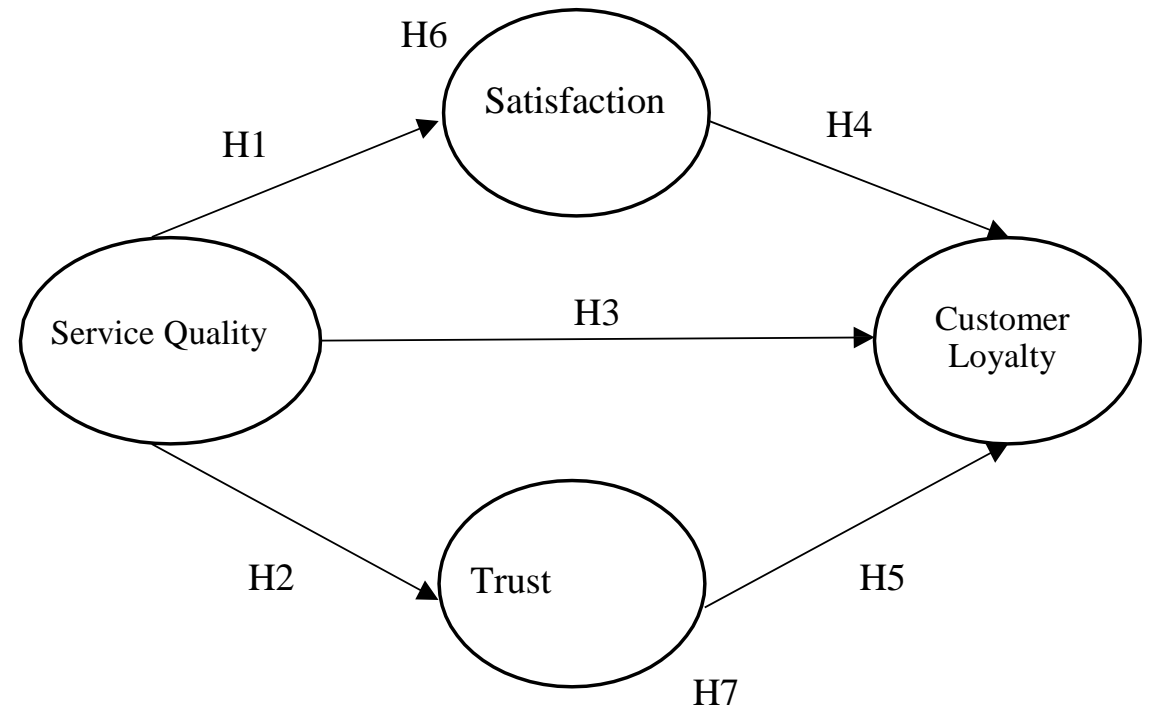

Figure 1 - Research Conceptual Framework 
A number of study results that discuss the relationship of the four variables as presented in Figure 1 are presented as follows. Jandavath's research (2016) a high level of hospital service quality will lead to a high level of patient satisfaction. The dimension of service quality is an important antecedent of customer satisfaction, car repair entrepreneurs in Ebonyi state, need to improve service quality for customer satisfaction (Izogo, 2015). The same results were found in the research of Ahmadi (2018), Gera (2011), Kitapcia, (2014), where there is a positive and significant relationship between service quality and satisfaction. Based on previous research, the following hypothesis is formulated:

H1: Service quality has a positive effect on satisfaction.

According to research by Bernardo et al., (2019), service quality has a positive effect on trust. The better the quality of service, the impact on increasing trust. The importance of service quality through the ease of use built by Grab will increase the trust of users of the application (Rizan et al., 2019). Similar results were found in the study of Namahoot et al. (2018), Montazemi and Qahri-Saremi (2015), Ofori et al. (2018), where there is a positive and significant relationship between service quality and trust. Based on previous research, the following hypothesis is formulated:

H2: Service quality has a positive effect on trust.

According to Liang's research (2019), high service quality, perceived value, and company image are very important for customer loyalty. Click and mortar malls that want to increase customer loyalty must provide real, reliable and guaranteed services. Service quality has a positive and significant effect on customer loyalty. Therefore, the higher the quality of services provided by Islamic banks, the more loyal Muslim customers in Indonesia will be (Asnawi, 2019). Similar results were found in the research of Basri (2019), Altaf et al. (2019), Minh and Huu (2016), where there is a positive and significant relationship between service quality and customer loyalty. Based on previous research, the following hypothesis is formulated:

H3: Service quality has a positive effect on customer loyalty.

The research of Firmansyah et al. (2018), customer loyalty is a form of manifestation and continuation of customer satisfaction in using electric train services at Manggarai Station. Customer satisfaction is obtained from the fulfillment of customer expectations for electric train services at Manggarai Station. When customer satisfaction is higher, it will be able to generate profits. Satisfied customers will make repeat purchases. And vice versa, if there is no satisfaction, it can result in customers moving to other transportation services. Satisfied customers have a high level of loyalty to supermarkets in Fiji (Slack, 2019). Similar results were found in the study of Omorigie et al. (2019), Fakhrana (2020), Ali and Naem (2019), where there is a positive and significant relationship between satisfaction and customer loyalty. Based on previous research, the following hypothesis is formulated:

H4: Satisfaction has a positive effect on customer loyalty.

Research by Haron et al., (2020), trust has a positive and significant effect on loyalty. Customer trust builds a long term relationship with the bank, which in turn can result in satisfied customers having great trust in the bank, and this will enhance the long term relationship even further. Customer trust has a significant relationship with customer loyalty at PT Bank Syariah Indonesia, which can build sustainable customer trust by improving sharia bank business operations that pay more attention to Islamic principles and laws (Fauzi 2018). Similar results were found in Butt and Aftab (2013), Kishada and Wahab (2013), Nguyen et al. (2013), where there is a positive and significant relationship between trust and customer loyalty. Based on previous research, the following hypothesis is formulated:

H5: Trust has a positive effect on customer loyalty.

In Slack's research (2019), satisfaction partially mediates the relationship between service quality and customer loyalty in the supermarket sector in Fiji. The satisfaction of Muslim customers in Indonesia related to Islamic commercial banking services has a direct relationship with customer loyalty (Asnawi et al., 2019). The same results were found in the study of Firmansyah et al. (2018), Hartono and Salim (2020), Gunawan and Kempa (2016), satisfaction can mediate the relationship between service quality and customer loyalty. Based on previous research, the following hypothesis is formulated: 
H6: Satisfaction is able to significantly mediate the effect of quality.

Hartono and Salim's (2020) research shows that service quality affects customer loyalty which is mediated by customer satisfaction and trust. Customer trust positively mediates the relationship between service quality and customer loyalty at PT. Bank Pembangunan Bali Cabang Renon. That is, the better the quality of service provided and able to meet customer expectations, it can form the trust of these customers, with a high sense of trust, it can lead to customer loyalty towards PT. Bank Pembangunan Bali Cabang Renon (Pramana and Jatra 2017). Similar results were found in the research of Pramana and Rastini (2016), Safitri and Nurkhin (2019), Osman and Sentosa (2013), trust can mediate the relationship between service quality and customer loyalty. Based on previous research, the following hypothesis is formulated:

H7: Trust is able to significantly mediate the effect of service quality on customer loyalty.

\section{METHODS OF RESEARCH}

This study discusses the behavior of Indihome customers in Denpasar City in assessing the variables of service quality, satisfaction, trust and customer loyalty. The population of this study is Indihome customers who are registered at Telkom Indonesia in Bali and based in Denpasar City. However, data about the population cannot be accessed because it is company secret so that in this case the population cannot be known by the researcher. This study has 16 indicators and questionnaires were distributed to 160 respondents.

Operationally, the quality of service in this study is the customer's perception of service quality at Indihome. The indicators in this service quality variable are based on the studies of Natalia, et al. (2020), Darwin and Kunto (2014), and Gunawan and Kempa (2016), namely: 1) Means of communication, 2) Providing services as promised, 3) Establishing good communication with customers, 4) Fast in providing services.

Satisfaction in this study is the customer's positive response after using Indihome. The indicators of this satisfaction variable are based on the studies of Ruslim and Rahardjo (2016), Laely (2016), Saputra and Sudarsa (2019) and Fakhrana (2020), namely: 1) Customers are happy to use services, 2) Meet customer expectations, 3) Provide a satisfying experience 4) The ability of customer service to handle complaints

Trust in this study is the positive attitude of customers who believe in Indihome because it is in line with their expectations. The indicators used in this trust variable are based on the studies of Fian (2016), Alkadrie (2018) and Ermiyenti (2019), namely: 1) Customers trust personnel, 2) Companies can be trusted by customers, 3) Trust in good service, 4) Believe in company reputation.

Customer loyalty in this study is the attitude and behavior of customers towards Indihome's performance, which refers to making repeat purchases and sharing positive experiences. The indicators used in this customer loyalty variable are based on the studies of Laely (2016), Mujito, et al. (2017), Rofiah and Wahyuni (2017) and namely: 1) Will recommend to others, 2) Will stay subscribed, 3) Buy outside the product/service line, 4) Resistant to competitors.

Data were collected using a questionnaire on google-form, then analyzed using descriptive statistics in the form of arithmetic mean and inferential statistics in the form of SEM-PLS. The four variables were measured through a number of indicators and each indicator was measured using a five-point Likert Scale ranging from strongly disagree to strongly agree.

\section{RESULTS OF STUDY}

Testing of the research instrument shows the results where all the statement items in the questionnaire have a validity coefficient above 0.3 which means it is valid or according to what is measured, while the reliability coefficient of each variable is reliable because it has a 
Cronbach Alpha value of each variable greater than 0.6. Descriptions of research variables seen from the distribution of respondent's answers and their averages are presented in Table 1.

Table 1 - Distribution of Respondent's Answers to Research Variables

\begin{tabular}{|c|c|c|c|c|c|c|c|c|}
\hline \multirow[t]{2}{*}{ No } & \multirow[t]{2}{*}{ Variables/Indicators } & \multicolumn{2}{|c|}{$\begin{array}{l}\text { Frequency } \\
\text { Answers }\end{array}$} & \multirow{2}{*}{$\begin{array}{l}\text { of } \\
3\end{array}$} & \multicolumn{2}{|c|}{ Respondent's } & \multirow[t]{2}{*}{ Average } & \multirow[t]{2}{*}{ Criteria } \\
\hline & & 1 & 2 & & 4 & 5 & & \\
\hline & Service Quality & & & & & & & \\
\hline 1 & $\begin{array}{l}\text { The My Indihome application is complete in providing } \\
\text { information }\end{array}$ & 2 & 6 & 40 & 49 & 63 & 4,03 & Good \\
\hline 2 & The internet speed offered by Indihome is as promised & 4 & 17 & 46 & 45 & 48 & 3,73 & Good \\
\hline 3 & Indihome has a responsive customer service & 2 & 11 & 45 & 45 & 57 & 3,90 & Good \\
\hline \multirow[t]{3}{*}{4} & $\begin{array}{l}\text { Indihome employees are quick to respond to customer } \\
\text { complaints }\end{array}$ & 4 & 17 & 38 & 44 & 57 & 3,83 & Good \\
\hline & The overall average of service quality variables & & & & & & 3,87 & Good \\
\hline & Satisfaction & & & & & & & \\
\hline 1 & I'm happy to subscribe to Indihome & 5 & 11 & 50 & 46 & 48 & 3,76 & High \\
\hline 2 & I feel the suitability of what is given by Indihome & 3 & 15 & 51 & 46 & 45 & 3,72 & High \\
\hline 3 & I had a good experience while subscribing to Indihome & 6 & 13 & 45 & 49 & 47 & 3,74 & High \\
\hline \multirow[t]{3}{*}{4} & $\begin{array}{l}\text { I am satisfied with the speed of Indihome customer service } \\
\text { in handling complaints }\end{array}$ & 3 & 13 & 55 & 37 & 52 & 3,76 & High \\
\hline & Average overall satisfaction variable & & & & & & 3,74 & High \\
\hline & Trust & & & & & & & \\
\hline 1 & I believe Indihome employees are doing a good job & 2 & 3 & 37 & 47 & 71 & 4,14 & High \\
\hline 2 & I believe Indihome puts its customers first & 2 & 4 & 43 & 48 & 63 & 4,04 & High \\
\hline 3 & I believe Indihome provides good service & 5 & 4 & 45 & 48 & 58 & 3,94 & High \\
\hline \multirow[t]{3}{*}{4} & I believe Indihome has a good reputation & 3 & 8 & 39 & 50 & 60 & 3,98 & High \\
\hline & The overall average of the trust variables & & & & & & 4,02 & High \\
\hline & Customer Loyalty & & & & & & & \\
\hline 1 & I will recommend Indihome to people around & 6 & 15 & 47 & 40 & 52 & 3,73 & High \\
\hline 2 & I will continue to subscribe to Indihome & 4 & 15 & 47 & 41 & 53 & 3,78 & High \\
\hline 3 & I use additional services other than internet on Indihome & 11 & 18 & 45 & 36 & 50 & 3,60 & High \\
\hline \multirow[t]{2}{*}{4} & I will not be influenced by competitor's product offerings & 13 & 21 & 48 & 40 & 38 & 3,43 & High \\
\hline & The overall average of customer loyalty variables & & & & & & 3,63 & High \\
\hline
\end{tabular}

Based on Table 1, the average score of the service quality variable is 3.87 with good criteria. The highest average value is 4.03 (good) while the lowest average value is 3.73 (good). The average score of the satisfaction variable is 3.74 with high criteria. The highest average value is 3.76 (high) while the lowest average value is 3.72 (high). The average score of the trust variable is 4.02 with high criteria. The highest average score is 4.14 (high) while the lowest average value is 3.94 (high). The average score of the customer loyalty variable is 3.63 with high criteria. The highest average score is 3.78 (high) while the lowest average score is 3.43 (high).

Table 2 - Direct Effect Test Results

\begin{tabular}{|c|c|c|c|c|c|c|c|}
\hline & & $\begin{array}{l}\text { Original } \\
\text { Sample (O) }\end{array}$ & $\begin{array}{l}\text { Sample } \\
\text { Mean (M) }\end{array}$ & $\begin{array}{l}\text { Standard Deviation } \\
\text { (STDEV) }\end{array}$ & $\begin{array}{l}\text { T } \quad \text { Statistics } \\
(|\mathrm{O} / \mathrm{STDEV}|)\end{array}$ & $\begin{array}{l}\mathrm{P} \\
\text { Values }\end{array}$ & Conclusion \\
\hline $\begin{array}{l}\text { Service Quality } \\
\text { Satisfaction }\end{array}$ & $->$ & 0.856 & 0.858 & 0.026 & 33.568 & 0.000 & Significant \\
\hline Service Quality -> Trus & & 0.830 & 0.832 & 0.025 & 32.771 & 0.000 & Significant \\
\hline $\begin{array}{l}\text { Service Quality } \\
\text { Customer Loyalty }\end{array}$ & $->$ & 0.201 & 0.197 & 0.092 & 2.171 & 0.030 & Significant \\
\hline $\begin{array}{l}\text { Satisfaction } \\
\text { Customer Loyalty }\end{array}$ & $->$ & 0.548 & 0.551 & 0.085 & 6.475 & 0.000 & Significant \\
\hline $\begin{array}{lll}\begin{array}{l}\text { Trust } \\
\text { Loyalty }\end{array} & -> & \text { Custom } \\
\end{array}$ & & 0.183 & 0.184 & 0.079 & 2.317 & 0.021 & Significant \\
\hline
\end{tabular}

Source: Primary data processed, 2021.

Based on Table 2, the results of hypothesis testing show that all hypotheses have a pvalue of 0.005 , which means that all hypotheses are accepted, this result also shows the direct effect of one variable on another variable. The mediating role of the variables of trust and satisfaction is shown in Table 3 and Table 4. 
Table 3 - Indirect Effect Test Results

\begin{tabular}{lllll}
\hline \multirow{2}{*}{ Variable Mediation } & Effect & & \\
\cline { 2 - 5 } & $(\mathrm{A})$ & $(\mathrm{B})$ & $(\mathrm{C})$ & $(\mathrm{D})$ \\
\hline Service Quality)-> Satisfaction $(\mathrm{M} 1)->$ Customer Loyalty $(\mathrm{Y})$ & 0.469 & 0.201 & 0.856 & 0.548 \\
\hline Service quality $(\mathrm{X})->$ Trust $(\mathrm{M} 2)->$ Customer loyalty $(\mathrm{Y})$ & 0.152 & 0.201 & 0.830 & 0.183 \\
\hline
\end{tabular}

Source: Primary data processed, 2021.

Table 4 - Direct Effect, Indirect Effect, Total Variable Effect and Calculation of VAF

\begin{tabular}{|c|c|c|}
\hline \multirow{2}{*}{ Variable } & \multicolumn{2}{|l|}{ Direct effect } \\
\hline & Coefficient Correlation & $t$-Statistics \\
\hline Service Quality (X) -> Satisfaction (M1) & 0.856 & 33.568 \\
\hline Service Quality (X) -> Trust (M2) & 0.830 & 32.771 \\
\hline Service quality $(\mathrm{X})->$ Customer loyalty $(\mathrm{Y})$ & 0.201 & 2.171 \\
\hline Satisfaction (M1) -> Customer Loyalty (Y) & 0.548 & 6.475 \\
\hline Trust (M2) -> Customer Loyalty $(\mathrm{Y})$ & 0.183 & 2.317 \\
\hline \multirow{2}{*}{ Variable } & \multicolumn{2}{|l|}{ Indirect effect } \\
\hline & Coefficient Correlation & $t$-Statistics \\
\hline Service Quality (X) -> Satisfaction (M1) -> Customer Loyalty $(\mathrm{Y})$ & 0.469 & 6.290 \\
\hline Service quality $(\mathrm{X})->$ Trust $(\mathrm{M} 2)$-> Customer loyalty $(\mathrm{Y})$ & 0.152 & 2.265 \\
\hline \multirow{2}{*}{ Variable } & \multicolumn{2}{|l|}{ Total effect } \\
\hline & Coefficient Correlation & $t$-Statistics \\
\hline Service Quality -> Satisfaction & 0.856 & 33.568 \\
\hline Service Quality -> Trust & 0.830 & 32.771 \\
\hline Service Quality -> Customer Loyalty & 0.821 & 31.589 \\
\hline Satisfaction -> Customer Loyalty & 0.548 & 6.475 \\
\hline \multirow[t]{2}{*}{ Trust -> Customer Loyalty } & 0.183 & 2.317 \\
\hline & \multicolumn{2}{|l|}{ VAF value } \\
\hline VAF -> Indirect Effect / Total Effect (0.469/0.670) & \multicolumn{2}{|l|}{0.700} \\
\hline VAF -> Indirect Effect / Total Effect (0.152/0.353) & \multicolumn{2}{|l|}{0.431} \\
\hline
\end{tabular}

Source: Primary data processed, 2021.

The test results as shown in Table 3 show that the effect of all tested variables (A to D) has a significant coefficient. Thus, satisfaction and trust are able to mediate the effect of service quality on customer loyalty. The role of satisfaction as a mediation can be seen in Table 4 where the VAF value is 0.700 . This figure is in the range of 20 percent to 80 percent, so it can be stated that this variable is classified as a partial mediating variable. Based on these results, it can be interpreted that satisfaction is able to partially mediate the effect of service quality on customer loyalty but is not strong, because of a decrease in the value of the direct effect of service quality on customer loyalty with an indirect effect.

The role of the trust variable as a mediation can be seen in Table 4 where the VAF value is 0.431 . This figure is in the range of 20 percent to 80 percent, so it can be stated that the variable is classified as a partial mediation variable. Based on these results, it can be interpreted that trust is able to partially mediate the effect of service quality on customer loyalty but is not strong, because of a decrease in the value of the direct effect of service quality on customer loyalty with an indirect effect.

\section{DISCUSSION OF RESULTS}

The effect of service quality on satisfaction. The results of the analysis show that service quality has a positive and significant effect on satisfaction. This means that the better the quality of service perceived by Indihome customers, the higher the customer satisfaction. Vice versa, the worse the quality of Indihome's services, the lower customer satisfaction. Service quality is measured by indicators: means of communication, providing services as promised, establishing good communication with customers, and being fast in providing services. The highest indicator on the service quality variable is establishing good communication with customers and the highest indicator on satisfaction is a satisfying experience. This means that Indihome's service quality in establishing good communication 
will improve a satisfying customer experience. The results of this study are in accordance with the results of previous research by Jandavath (2016), service quality has a positive and significant effect on patient satisfaction in hospitals in Chennai City, India. These results are also in accordance with research conducted by Izogo (2015), Ahmadi (2018), Gera (2011) and Kitapcia (2014).

The effect of service quality on trust. The results of the analysis show that service quality has a positive and significant effect on trust. This means that the better the quality of service perceived by Indihome customers, the higher the customer trust will be. Vice versa, the worse the quality of Indihome's services, the lower the customer's trust. Service quality is measured by indicators: means of communication, providing services as promised, establishing good communication with customers, and being fast in providing services. The highest indicator on the service quality variable is establishing good communication with customers and the highest indicator on trust is that the company can be trusted. This means that Indihome's service quality in establishing good communication will increase customer trust in the company. The results of this study are in accordance with previous research by Rizan et al (2019), service quality has a positive and significant effect on trust in Grab users in the Jakarta area. These results are also in accordance with research conducted by Bernarto et al., (2019), Namahoot et al., (2018), Montazemi and Qahri (2015) and Ofori et al., (2018).

The effect of service quality on customer loyalty. The results of the analysis show that service quality has a positive and significant effect on customer loyalty. This means that the better the quality of service perceived by Indihome customers, the higher the customer loyalty. Vice versa, the worse the quality of Indihome's services, the lower the customer loyalty. Service quality is measured by indicators: means of communication, providing services as promised, establishing good communication with customers, and being fast in providing services. The highest indicator of the service quality variable is establishing good communication with customers and the highest indicator of customer loyalty is resubscribing. This means that the quality of Indihome services in establishing good communication will increase the desire to stay subscribed. The results of this study are in accordance with previous research by Liang (2019), service quality has a positive and significant effect on customer loyalty for Click and mortar malls in Taiwan. These results are also in accordance with research conducted by Asnawi (2019), Basri (2019), Minh and Huu (2016) and Altaf et al., (2019).

The effect of satisfaction on customer loyalty. The results of the analysis show that satisfaction has a positive and significant effect on customer loyalty. This means that the higher the satisfaction felt by Indihome customers, the higher customer loyalty. Vice versa, the lower the satisfaction, the lower the customer loyalty. Satisfaction is measured by indicators, namely: the pleasure of using the service, meeting customer expectations, satisfying experience and the ability of customer service to handle complaints. The highest indicator on the satisfaction variable is a satisfying experience and the highest indicator on the customer loyalty variable is re-subscribe. This means that the higher the satisfying experience in subscribing to Indihome, the higher the taste for re-subscribing. The results of this study are in accordance with previous research by Firmansyah et al (2018), satisfaction has a positive and significant effect on customer loyalty for electric train services at Manggarai Station. These results are also in accordance with research conducted by Slack (2019), Omorigie et al. (2019), Ali and Naem (2019) and Fakhrana (2020).

The effect of trust on customer loyalty. The results of the analysis show that trust has a positive and significant effect on customer loyalty. This means that the higher the trust felt by Indihome customers, the higher customer loyalty. Vice versa, the lower the trust, the lower the customer loyalty. Trust is measured based on indicators, namely: trust in employees, a trustworthy company, trust in good service and trust in the company's reputation. The highest indicator on the trust variable is the company can be trusted and the highest indicator on the customer loyalty variable is re-subscribe. This means that the higher the customer's trust in Indihome, the greater the feeling of re-subscribing. The results of this study are in accordance with previous research by Haron et al (2020), trust has a positive and significant 
effect on customer loyalty of Islamic banks in Malaysia. These results are also in accordance with research conducted by Fauzi (2018), Nguyen et al. (2013), Khisada and Wahab (2013) and Butt and Aftab (2013).

The role of satisfaction in mediating the effect of service quality on customer loyalty. The results of the analysis show that satisfaction is able to mediate the effect of service quality on customer loyalty. Satisfaction in this study is a partial mediation, which means that the better the quality of Indihome's services, the more satisfaction it can create so as to increase customer loyalty. Based on these results, it can be interpreted that the satisfaction variable is not able to fully mediate the effect of service quality on customer loyalty. The results of this study are in accordance with previous research by Firmansyah et al (2020), which stated that satisfaction was able to mediate service quality on customer loyalty for the Jabotabek KRL. These results are also in accordance with research conducted by Slack (2019), Asnawi et al. (2019), Hartono and Salim (2020) and Gunawan and Kempa (2016).

The role of trust in mediating the effect of service quality on customer loyalty. The results of the analysis show that trust is able to mediate the effect of service quality on customer loyalty. Trust in this study is a partial mediation, which means that the better the quality of Indihome services, the more trust can be created so as to increase customer loyalty. Based on these results, it can be interpreted that the trust variable is not able to fully mediate the effect of service quality on customer loyalty The results of this study are in accordance with previous research by Pramana and Jatra (2017), which stated that trust was able to mediate service quality on customer loyalty at PT. Bank Pembangunan Daerah Bali Cabang Renon. These results are also in accordance with research conducted by Osman and Sentosa (2013), Safitri and Nurkhin (2019), Hartono and Salim (2020) and Pramana and Rastini (2016).

Research Limitations. This research has been carried out optimally, but still has the following limitations: The study was conducted in Denpasar City so it cannot be generalized to other wider areas. Data collection is done based on cross section. In a certain period of time while the environment changes so this research is important to do in the future.

\section{CONCLUSION}

Based on the data analysis and discussion that has been carried out, the conclusions of this study are as follows: service quality has a positive and significant effect on satisfaction. Service quality has a positive and significant effect on trust. Service quality has a positive and significant effect on customer loyalty. Satisfaction has a positive and significant effect on customer loyalty. Trust has a positive and significant effect on customer loyalty. Satisfaction is able to mediate the effect of service quality on customer loyalty. Satisfaction in the study is as a partial mediation. Trust is able to mediate the effect of service quality on customer loyalty. Trust in research is as partial mediation.

Based on the analysis and conclusions, the authors give some suggestions as follows: Improve infrastructure and replace a newer router, so that the signal reception becomes better and more stable. This is because there are still many customers who complain about unstable network problems. Evaluating the suitability of products/services to be provided to customers or potential customers. This can be done by first trying the stability of the network in each area that will be targeted and in handling customer complaints it must be more in line with the subject matter. Improve training for employees in order to create employees who are fast, alert and responsive. Then the company needs to routinely maintain and check every infrastructure that has been installed in order to maintain the stability of the existing network.

\section{REFERENCES}

1. Abror, A. \& Patrisia, D. 2019. Service quality, religiosity, customer satisfaction, customer engagement and Islamic bank's customer loyalty, Journal of Islamic Marketing, 1-15.

2. Ahmadi, A. 2018. Thai Airways: key influencing factors on customers' word of mouth, International Journal of Quality \& Reliability Management, 1:19. 
3. Akamavi, R.K., Mohamed, E., Pellmann, K. and Xu, Y. 2015. Key determinants of passenger loyalty in the low-cost airline business, Tourism Management, 46: 528-545.

4. Altaf, M., Tanveer, M., Mustafa, F., \& Mushtaq, N, 2019, Relationship of service quality and consumer loyalty: Moderating role of consumer perception of public relationship, 13 (1): 26-32.

5. Ali, S.F. and Naeem, M. 2019. Does service quality increase the level of banks performance. Comparative analysis between conventional and Islamic banks, Journal of Management Development, 38 (6): 442-454.

6. Alkadrie, S. A. 2018. Analisis pengaruh kualitas layanan, kepercayaan and komitmen terhadap loyalitas anggota pada cu lantang tipo cabang balai karangan kabupaten sanggau. Jurnal Ekonomi STIEP (JES), 3(1): 18-28.

7. Asnawi,N., Sukoco, B., M., Fanani, M., A. 2019, The role of service quality within Indonesian customers satisfaction and loyalty and its impact on Islamic banks, Journal of Islamic Marketing, 11 (1): 192-212.

8. Basri, A. I. 2019. Pengaruh Kualitas Layanan Terhadap Kepuasan and Loyalitas Nasabah Bank Pengguna E-Banking, 2 (1): 1-18.

9. Bernarto, I., Wilson, N., Suryawan, I., S. 2019, Pengaruh Website Design Quality, Service Quality, Trust and Satisfaction Terhadap Repurchase Intention (Studi Kasus: tokopedia.com), Jurnal Manajemen Indonesia, 19 (1): 80-90.

10. Bruneau, V., Swaen, V. \& Zidda, P. 2018, Are loyalty program members really engaged? Measuring customer engagement with loyalty programs, Journal of Business Research, 91: 144-158.

11. Butt, M.M. \& Aftab, M. 2013, Incorporating attitude towards halal banking in an integrated service quality, satisfaction, trust and loyalty model in online Islamic banking context, International Journal of Bank Marketing, 31 (1): 6-23.

12. Darwin, S. and Kunto, Y., S. 2014, Analisi Pengaruh Kualitas Layanan Terhadap Loyalitas Pelanggan Dengan Kepuasa and Kepercayaan Pelanggan Sebagai Variabel Intervening Pada Asuransi Jiwa Manulife Indonesia, Surabaya, Jurnal Manajemen Pemasaran Petra, 2 (1): 1-12.

13. Engko, C., Usmany, P. 2020. Dampak Pandemi Covid-19 Terhadap Proses Pembelajaran Online (Studi Eksploratif Pada Mahasiswa Jurusan Akuntansi Fakultas Ekonomi and Bisnis Universitas Pattimura), Jurnal Akuntansi , 6 (1): 23-38.

14. Ermiyenti, 2019, Pengaruh Kepercayaan and Kepuasan Pelanggan Terhadap Loyalitas Pelanggan Pada Bengkel UD. Benteng Honda Motor Medan, 3 (2): 144- 151.

15. Fakhrana, Z. 2020, Peran Kualitas Layanan and Kepercayaan Dalam Membangun Kepuasan and Loyalitas Pelanggan, Jurnal Manajemen and Jurnal Akuntansi, 5 (2): 157171.

16. Fauzi, A. A. \& Suryani T. 2018. Measuring the effects of service quality by using CARTER model towards customer satisfaction, trust and loyalty in Indonesian Islamic banking, Journal of Islamic Marketing, 10 (1): 269-289.

17. Fian, J., A. 2016, Pengaruh Kepuasan and Kepercayaan Pelanggan Terhadap Loyalitas Pelanggan Auto 2000 Sungkono Surabaya Jurnal Ilmu and Riset Manajemen, 5 (6): 1:18.

18. Firmansyah, D., Prihandono, D. 2018. Pengaruh Kualitas Pelayanan and Perceived Value Terhadap Loyalitas Pelanggan Dengan Kepuasan, Management Analysis Journal, 7 (1): 121-128.

19. Gera, R. 2011. Modelling the service antecedents of favourable and unfavourable behaviour intentions in life insurance services in India An SEM study, 3 (2): 225-242.

20. Gunawan, L., \& Kempa, S. 2016, Pengaruh Kualitas Layanan Terhadap Loyalitas Dengan Kepuasan Sebagai Variabel Intervening Di Toko Bintang Terang, Agora, 4 (1): 424-434.

21. Han, H. and Hyun, S.S. 2018, Role of motivations for luxury cruise traveling, satisfaction, and involvement in building traveler loyalty, International Journal of Hospitality Management, 70:75-84.

22. Hanifa, O., Kurniawati, T., Rahmidani, R. 2018, Pengaruh Harga and Kualitas Layanan Terhadap Loyalitas Pelanggan Go-Jek Dengan Kepuasan Pelanggan Sebagai Variabel 
Mediasi Pada Mahasiswa Universitas Negeri Padang, 1 (4): 794-803.

23. Haron, R., and Subar, N., A. 2020, Service quality of Islamic banks: satisfaction, loyalty and the mediating role of trust, Islamic Economic Studies, 1-21.

24. Hartono, K., B., Salim, L. 2020, Pengalaman Pemasaran and Kualitas Layanan Terhadap Loyalitas Pelanggan Dengan Kepuasan Pelanggan and Kepercayaan Sebagai Variabel Mediasi, Jurnal Ekonomi and Bisnis, 23 (02): 20-30.

25. Izogo. 2015. Service quality, customer satisfaction and loyalty in automobile repair services sector, International Journal of Quality \& Reliability Management, 32 (3): 114131.

26. Jandavath, R., N. 2016. Healthcare service quality effect on patient satisfaction and behavioural intentions in corporate hospitals in India, International Journal of Pharmaceutical and Healthcare Marketing, 10 (1): 1-28.

27. Joni, I., Ramadhan, S., Akhyar, Y., Purnamasari S., A., Simbolon, P. 2020, Respon Orang Tua Dalam Mendampingi Anak Belajar Daring Pada Masa Pandemi Covid-19, 5 (1): 1-7.

28. Kishada, Z.M.E. \& Wahab, N.A. 2013, Factors affecting customer loyalty in Islamic banking: Evidence from Malaysian banks, International Journal of Business and Social Science, 4 (7): 264-273.

29. Kitapcia, O. 2014, The Impact of Service Quality Dimensions on Patient Satisfaction, Repurchase Intentions and Word-of-Mouth Communication in the Public Healthcare Industry, 148: 161-169.

30. Kotler, P., and Keller, K. L. 2016. Marketing Management. 15th Ed. New Jersey: Pearson.

31. Laely, N. 2016, Analisis Pengaruh Kepercayaan and Harga Terhadap Loyalitas Pelanggan Dimediasi Kepuasan Pada PT. Telkomsel di Kota Kediri, JMM17 Jurnal IImu Ekonomi \& Manajemen, 3 (2): 61 - 74.

32. Liang, C.C. 2019, Solo economy in Taiwan: a quality study of click-and-mortar malls, Asia Pacific Journal of Marketing and Logistics, 1-23.

33. Minh, N., G., Huu, N., H. 2016, The Relationship between Service Quality, Customer Satisfaction and Customer Loyalty: An Investigation in Vietnamese Retail Banking Sector, Journal of Competitiveness, 8 (2): 103 - 116.

34. Montazemi, A. R. and Qahri-Saremi, H. 2015, Factors affecting adoption of online banking: A meta analytic structural equation modeling study, Information \& Management, $52(2): 1-37$.

35. Mujito, Muharam, H., Purba, J., H. 2019, Hubungan Service Quality and Customer Trust Dengan Loyalitas Pengunjung Wisata Jungeland Adventure Theme Park Sentul Bogor, 4 (2): $59-78$.

36. Namahoot, K., S., Laohavichien, T. 2018, Assessing the intentions to use internet banking: the role of perceived risk and trust as mediating factors, International Journal of Bank Marketing, 1-25.

37. Natalia, I., Nurhayati, Apria, E., 2020, Kualitas Pelayanan and Fasilitas Fisik Terhadap Kepuasa Peserta Didik (Studi Pada LP3I College Purwakarta), 6 (1): 26-36.

38. Nguyen, N., Leclerc, A., LeBlanc, G. 2013, The Mediating Role of Customer Trust on Customer Loyalty, Journal of Service Science and Management, 6: 96-109.

39. Ofori, K.S., Boakye, K. and Narteh, B. 2018, Factors influencing consumer loyalty towards 3G mobile data service providers: evidence from Ghana, Total Quality Management \& Business Excellence, 29 (5): 580-598.

40. Omoregie, O., 2019. Factors influencing consumer loyalty: evidence from the Ghanaian retail banking industry, International Journal of Bank Marketing, 1-24.

41. Osman., Z and Sentosa, I 2013, Service Quality and Customer Loyalty in Malaysian Rural Tourism: A Mediating Effect of Trust, International Journal of Marketing Practices, 1 (1): 31-42.

42. Pramana, I., G., Y., Rastini, N., M. 2016, Pengaruh Kualitas Pelayanan Terhadap Kepercayaan Nasabah and Loyalitas Nasabah Bank Mandiri Cabang Veteran Denpasar Bali, E-Jurnal Manajemen Unud, 5 (1): 706-733. 
43. Pramana, I., K., B., Jatra, I., M. 2017, Peran Kepercayaan Nasabah Dalam Memediasi Pengaruh Kualitas Layanan Terhadap Loyalitas Nasabah, E-Jurnal Manajemen Unud, 6 (12): 6818-6844.

44. Pratiwi, E. W. 2020 Dampak Covid-19 Terhadap Kegiatan Pembelajaran Online Di Sebuah Perguruan Tinggi Kristen Di Indonesia, Perspektif IImu Pendidikan, 34 (1):1-8.

45. Raies, K., Mühlbacher, H. and Gavard-Perret, M.L. 2015, Consumption community commitment: newbies' and longstanding members' brand engagement and loyalty", Journal of Business Research, 68 (12): 2634-2644.

46. Rizan, M., Haro, A., Rahmadhina, B. 2019, Pengaruh Perceived Ease Of Use and Service Quality Terhadap Customer Satisfaction Dengan Trust Sebagai Intervening (Studi Kasus Pada Pengguna Grab Di Wilayah Jakarta), Jurnal Riset Manajemen Sains Indonesia (JRMSI), 10 (2): 337-355.

47. Rofiah, C., Wahyuni, D. 2017. Kualitas Pelayanan and Pengaruhnya Terhadap Loyalitas Pelanggan Yang Di Mediasi Oleh Kepuasan Di Bank Muamalat Jombang, EKSIS, 12 (1): 69-82.

48. Ruslim, T.S., and Rahardjo, M. 2016. Identifikasi Kepuasan Pelanggan Ditinjau Dari Segi Harga and Kualitas Pada Restoran Abuba Steak Di Greenville, Jurnal IImiah Manajemen and Bisnis, Vol. 2, No. 1. pp. 56-65.

49. Saputra, S., Sudarsa, R., Y., 2019, Pengaruh Kualitas Pelayanan Terhadap Kepuasan Pelanggan Di Grand Setiabudi Hotel \& Apartment, Jurnal Bisnis and Pemasaran, 9 (2): 21-31.

50. Safitri, D., Nurkhin, D. 2019. Pengaruh Kualitas Pelayanan Terhadap Loyalitas Muzaki Melalui Kepuasan Muzaki and Kepercayaan Muzaki, 8 (2): 501-515.

51. Slack, N., J. 2019, The effect of service quality on customer satisfaction and loyalty and the mediating role of customer satisfaction Supermarkets in Fiji, The TQM Journal, 32 (3): 543-558.

52. Widjoyo, S., Hatane, P., Brahmana, R. K. M. R., Pemasaran, J. M., Petra, U. K., \& Siwalankerto, J. 2014. Pengaruh kualitas layanan and kualitas produk terhadap kepuasan pelanggan and loyalitas restoran happy garden Surabaya, Manajemen Pemasaran, 2 (1): 1- 9.

53. https://www.cnnindonesia.com/teknologi/20200409181907-192-492233/netizen-cibirjaringan-indihome-sering-lambat-kala-wfh-corona. Diakses pada tanggal 1 Maret 2021.

54. https://nasional.kompas.com/read/2021/02/25/21010711/mewujudkan-akses-internetoptimal-secara-menyeluruh-di-tengah-pandemi. Diakses pada tanggal 1 Maret 2021.

55. https://www.speedtest.net/global-index/indonesia?fixed\#fixed. Diakses pada tanggal 1 Maret 2021.

56. https://ispspeedindex.netflix.net/country/indonesia. Diakses pada tanggal 1 Maret 2021.

57. https://market.bisnis.com/read/20201022/192/1308350/pelanggan-indihome-tumbuhsubur-di-masa-pandemi. Diakses pada tanggal 24 juli 2021. 